
\title{
СТРУКТУРНІ ЗМІНИ М'ЯЗІВ ЗАДНІХ КІНЦІВОК ЩУРІВ ПРИ ГОСТРІЙ ІШЕМІї
}

\begin{abstract}
Резюме. Гостра ішемія кінцівки виникає унаслідок обтурації просвіту великих артерій при гострому тромбозі чи емболії, а також порушенні прохідності судин, спричинене їх травмами чи стисненням (включаючи накладання кровоспинних турнікетів). У випадку ліквідації гострої ішемії і відновленні артеріального кровопостачання ураженої кінцівки виникає мультифракторне ураження ішемізованих та віддалених від місця ушкодження тканин, що носить назву реперфузійно-ішемічного синдрому. Мета дослідження - встановити прояви структурних змін м'язових волокон та мікроциркуляторного русла скелетних м'язів задніх кінцівок щурів при гострій ішемії, спричиненій накладанням артеріального турнікета.

Матеріали і методи. Проведено гістологічне та морфометричне дослідження тканин чотириголових м'язів задніх кінцівок 60 щурів за умов експериментальної гострої ішемії. У контрольній групі було 11 інтактних тварин. Гостру ішемію викликали шляхом накладання гумових джгутів SWAT (Stretch-Wrap-And-Tuck) на задні кінцівки тварин шириною 5-6 мм на рівні пахвинної складки протягом 2 год під тіопенталовим знеболюванням. Під час експерименту тварин поділили на 5 груп дослідження по 12 щурів у кожній групі. Модель раннього постішемічного періоду було представлено групами тварин із реперфузійними змінами на 1, 2 год та 1 добу після зняття турнікета, а модель пізнього постішемічного періоду - на 7 та 14 доби після зняття турнікету. Гістологічне дослідження проводили за загальноприйнятими методиками. Досліджували поверхневі шари чотириголового м'яза задньої кінцівки щура у середній третині стегна нижче ділянки накладання джгута. При морфометричному дослідженні визначали такі показники: пересічні діаметр м'язових волокон, площа поперечного перерізу м'язових волокон, діаметр та площа ядер м'язових волокон. Кількісні показники обробляли статистично.

Результати досліджень та їх обговорення. Результати всестороннього аналізу отриманих даних показали, що патологічні зміни м'язової тканини виникали вже в ранній період постішемічного ураження та наростали до кінця 1 доби. При гістологічному дослідженні спостерігали наступні зміни тканин м'язів: дезорганізацію структурних компонентів м'язових клітин, зменшення посмугованості, розрихленість, розволокненість та розриви м'язових волокон, порушення їх звивистості, нелінійне розміщення ядер, поява окремих некротичних ділянок та розташування ядер у міжклітинному просторі. Найзначніший набряк м'язової тканини мав місце на 1 добу в третій групі щурів $((41,73 \pm 0,39)$ мкм). Пересічний діаметр м'язових волокон у цій групі перевищував на $3,37 \%$ відповідний показник $((40,37 \pm 0,54)$ мкм) контрольної групи $(p<0,05)$. Пересічна площа ядер м'язових волокон $(64,03 \pm 0,08)$ мкм) у третій групі лише незначно перевищувала відповідний показник $((63,95 \pm 0,07)$ мкм) групи контролю $(p>0,05)$. Виявлене зменшення показника ядерно-цитоплазматичного співвідношення у другій $(0,047 \pm 0,001)$ та третій $(0,047 \pm 0,001)$ групах щурів, порівняно 3 відповідним показником групи контролю $(0,050 \pm 0,001)(p<0,05)$, може свідчити про зменшення ядерної активності клітин у результаті ішемічного ушкодження.

Висновки. Результати ремоделювання м'язових волокон та судин мікроциркуляторного русла підтверджують розвиток у піддослідних тварин ішемічно-реперфузійного синдрому. При дослідженні скелетної мускулатури задніх кінцівок білих щурів після гострої ішемії, спричиненої накладанням турнікета, встановлено, що ремоделювання м'язових волокон проявлялося в основному набуханням, гомогенізацією саркоплазми, порушенням лінійного розміщення ядер в міоцитах та лейкоцитарною інфрільтрацією ендо- і перимізію, міолізом із руйнуванням сарколеми та виходом ядер у міжклітинний простір. Реактивні порушення розвивались в мікросудинах усіх сегментів та були максимально вираженими до кінця першої доби.
\end{abstract}

Ключові слова: гостра ішемія; м'язова тканина; м'язове волокно; мікроциркуляторне русло; реперфузійно-ішемічний синдром.

ВСТУП Гострою ішемією визначають будь-яке раптове зниження перфузії кінцівки, що створює потенційну загрозу її життєздатності. Найчастішими причинами такого стану є обтурація просвіту великих артерій унаслідок гострого тромбозу чи емболії, а також порушення прохідності судин, спричинене їх травмами чи стисненням (включаючи накладання кровоспинних турнікетів) [1]. Частота виникнення гострої ішемії кінцівок складає 140 випадків на 1 млн населення в рік. Виявляють один випадок гострої ішемії в рік на 6000 населення [2, 3]. При ліквідації гострої ішемії і відновленні артеріального кровопостачання ураженої кінцівки виникає мультисракторне ураження ішемізованих та віддалених від місця ушкодження тканин, що носить назву реперфузійно-ішемічного синдрому [4-9].

Існує багато досліджень, що присвячені вивченню структурних змін м'яких тканин кінцівок при розвитку реперфузійно-ішемічного синдрому [10-12], проте недостатньо вивченими залишаються морфологічні зміни м'язової тканини у поєднанні з порушенням мікроциркуляції на місцевому рівні, а також динаміка цих змін.

Метою дослідження було встановити прояви структурних змін м'язових волокон та мікроциркуляторного русла скелетних м'язів задніх кінцівок щурів при гострій ішемії, спричиненій накладанням артеріального турнікета.
МАТЕРІАЛИ І МЕТОДИ Проведено гістологічне та морфометричне дослідження тканин чотириголових м'язів задніх кінцівок 60 щурів за умов експериментальної гострої ішемії. У контрольній групі було 11 інтактних тварин.

Гостру ішемію викликали шляхом накладення гумових джгутів SWAT на задні кінцівки тварин шириною 5-6 мм на рівні пахвинної складки протягом 2 год під тіопенталнатрієвим знеболюванням. Реперфузійний синдром моделювали шляхом відновлення кровообігу в раніше ішемізованих кінцівках після зняття турнікету. Спостерігали за тваринами протягом 14 діб.

Під час експерименту особин поділили на 5 груп дослідження. Модель раннього постішемічного періоду була представлена групами тварин із реперфузійними змінами на 1 год (12 щурів), 2 год (12 щурів) та 1-шу добу (12 щурів) після зняття турнікета, а модель пізнього постішемічного періоду - на 7 (12 щурів) та 14 доби (12 щурів) після зняття турнікета. Евтаназію тварин здійснювали шляхом декапітації під тіопентал-натрієвим знеболюванням.

Гістологічне дослідження проводили на кафедрі патологічної анатомії з секційним курсом та судової медицини ДВНЗ “Тернопільський державний медичний університет імені І. Я. Горбачевського МОЗ України" за загальноприйнятими методиками [13]. Досліджували поверхневі шари чотириголового м'яза задньої кінцівки щура у середній 
третині стегна нижче ділянки накладання джгута. 3 парафрінових блоків тканини готували серії зрізів товщиною 4-5 мкм, виготовлені на мікротомі МС-2. Гістологічні зрізи забарвлювали гематоксиліном та еозином. Вивчення препаратів здійснювали за допомогою мікроскопа Bresser.

При морфометричному дослідженні визначали такі показники: пересічний діаметр м'язових волокон, пересічну площу поперечного перерізу м'язових волокон, пересічні діаметр та площа ядер м'язових волокон. Дані параметри обчислювали за допомогою програмного забезпечення для обробки й аналізу зображень SEO Image Lab фрірми "Sumy Electron Optics".

Статистичну обробку матеріалу проводили з використанням пакета програм Microsoft Excel (Microsoft Office 2007). Визначали такі показники: середнє арифметичне (M), середнє квадратичне відхилення (б) і помилку середнього арифметичного (m). Статистичну значущість різниці між середніми арифрметичними та відносними величинами оцінювали за критерієм Стьюдента-Фішера (t).

РЕЗУЛЬТАТИ ДОСЛІДЖЕНЬ ТА ЇХ ОБГОВОРЕННЯ При гістологічному дослідженні спостерігали такі зміни тканин чотириголових м'язів задніх кінцівок білих щурів. У перші дві години після зняття турнікета (перша та друга групи дослідження) виявляли дезорганізацію структурних компонентів м'язових клітин, зменшення посмугованості, розрихленість, розволокненість та розриви м'язових волокон (рис. 1). Мало місце порушення їх звивистості та нелінійне розміщення ядер. Виявлялись фрібрили із слабоеозинофільною цитоплазмою без ядер, що свідчило про цитоліз. Такі зміни наростали до кінця першої доби (третя група дослідження), ставали більш інтенсивними та дифуузими. Спостерігали також окремі некротичні ділянки та розташування ядер у міжклітинному просторі. Волокна фррагментувалися на ряд послідовно розташованих глибок. Навколо таких ділянок візуалізувалися скупчення лімфоцитів. Подібні зміни були і на 7 добу (четверта група), проте вони були менш інтенсивними та виявлялись локально. Набряк волокнистої периваскулярної сполучної тканини, перимізію та ендомізію поєднувався із проліферацією сполучнотканинних елементів. На 14-ту добу (п'ята група) виявлялося майже повне відновлення м'язової тканини з окремими осередками розростання волокнистої сполучної тканини та клітинної інфрільтрації. М'язові волокна на поперечних зрізах мали однорідну структуру, ядра чітко визначалися під сарколемою, орієнтуючись своєю довгою віссю паралельно їй.

Ішемічний набряк наростав від перших годин до кінця першої доби (табл. ). Пересічний діаметр поперечного перерізу м'язових волокон на 1 год (перша група) після зняття турнікета $((40,77 \pm 0,76)$ мкм) на 0,99 \% перевищував відповідний показник контрольної групи $((40,37 \pm 0,54)$ мкм) (p>0,05). Через 2 год після зняття турнікета (друга група) пересічний діаметр м'язових волокон $((41,67 \pm 0,34)$ мкм) перевищував на 2,21 \% аналогічний показник першої групи (p>0,05) та на 3,20 \% - відповідний показник групи контролю $(p<0,05)$. Найзначніший набряк м'язової тканини мав місце на 1-шу добу (третя група щурів). Пересічний діаметр м'язових волокон $((41,73 \pm 0,39)$ мкм) у зазначеній групі перевищував на $3,37 \%$ відповідний показник контрольної групи $(p<0,05)$, на 2,36 \% - відповідний показник першої групи $(p>0,05)$ та на 0,14 \% - аналогічний показник другої групи ( $>>0,05)$.

На 7 добу (четверта група) була тенденція до зменшення пересічного діаметра м'язових волокон $((41,58 \pm 0,42)$ мкм). Цей показник був на 0,36 \% нижчим, порівняно 3 аналогічним показником третьої та на 0,22 \% - із відповідним показником другої груп. Проте виявлявся на 1,99 \% більшим, порівняно з аналогічним показником першої групи, та на 2,98 \% - із аналогічним показником групи контролю (p>0,05). На 14-ту добу після зняття турнікета пересічний діаметр м'язових волокон $((40,81 \pm 0,43)$ мкм) суттєво не різнився із відповідним показником групи контролю ( $>0,05)$, проте був суттєво нижчим порівняно 3 аналогічним показником третьої групи $(p<0,05)$.

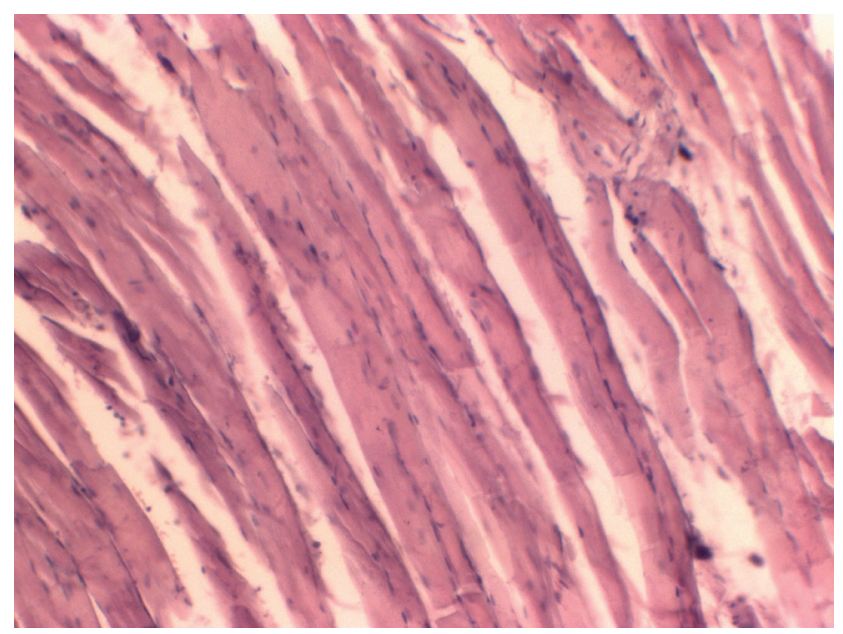

Рис. 1. Повздовжній зріз чотириголового м'яза щура. Фрагментація, втрата посмугованості м'язових волокон, порушення лінійного розташування ядер, наявність окремих ядер у міжклітинному просторі. Набряк інтерстиціального простору. Друга година після зняття турнікета. Забарвлення гематоксиліном та еозином. ×100.

Набряк ядер м'язових волокон був відносно менше виражений. Найвищий пересічний показник був на 1 добу спостереження (третя група). Пересічна площа ядер зазначеної групи $(64,03 \pm 0,08)$ мкм) незначно перевищувала відповідний показник першої $((63,98 \pm 0,08)$ мкм, p>0,05) та другої груп $((63,99 \pm 0,12)$ мкм, $p>0,05)$. При цьому пересічний діаметр ядер м'язових волокон у першій групі також несуттєво $(p>0,05)$ різнився від аналогічного показника контрольної групи ((63,95ะ0,07) мкм). У другій групі пересічний діаметр ядер м'язових волокон перевищував аналогічний показник контрольної групи та відповідний показник першої групи, проте статистично достовірної відмінності не виявлялось ( $>>0,05)$.

У четвертій групі дослідження було зменшення пересічного діаметра ядер м'язових волокон. Цей показник $((64,01 \pm 0,08)$ мкм) був нижчим, порівняно з аналогічним показником третьої групи, та виявлявся вищим порівняно 3 аналогічним показником першої та другої груп та групи контролю (p>0,05). На 14 добу після зняття турнікета (п'ята група) пересічний діаметр ядер м'язових волокон $((63,78 \pm 0,09)$ мкм) мав тенденцію до зниження, порівняно з третьою групою, проте статистично значущої відмінності не виявлено ( $p>0,05)$.

Спостерігали зменшення показника ядерно-цитоплазматичного співвідношення у другій $(0,047 \pm 0,001)$ та третій $(0,047 \pm 0,001)$ групах щурів порівняно з відповідним показником групи контролю $(0,050 \pm 0,001)(p<0,05)$. Виявлялась також тенденція до збільшення показника ядерноцитоплазматичного співвідношення у п'ятій $(0,049 \pm 0,001)$ групі, порівняно з третьою групою дослідження, проте ця відмінність була статистично незначущою ( $>>0,05)$ (табл.). 
Таблиця. Зміни пересічних діаметра (d), площі $\left(\mathrm{s}_{\mathrm{s}}\right)$ м'язових волокон, площі їх ядер $\left(\mathrm{s}_{\mathrm{n}}\right)$ та ядерно-цитоплазматичного співвідношення $\left(\mathrm{s}_{\mathrm{n}} / \mathrm{s}_{\mathrm{s}}\right)$ в ділянці стегна білих щурів у різні періоди після зняття турнікета $(\mathrm{M} \pm \mathrm{m})$

\begin{tabular}{|l|l|l|l|l|l|l|}
\hline Показник & Контроль & $\begin{array}{l}\text { Перша група, } \\
1 \text { год }\end{array}$ & $\begin{array}{l}\text { Друга група, } \\
2 \text { год }\end{array}$ & $\begin{array}{l}\text { Третя група, } \\
1 \text { доба }\end{array}$ & $\begin{array}{l}\text { Четверта група, } \\
7 \text { доба }\end{array}$ & $\begin{array}{l}\text { П'ята група, } \\
14 \text { доба }\end{array}$ \\
\hline $\mathrm{d}($ мкм $)$ & $40,37 \pm 0,56$ & $40,77 \pm 0,79$ & $41,67 \pm 0,35^{*}$ & $41,73 \pm 0,41^{*}$ & $41,58 \pm 0,43$ & $40,81 \pm 0,44^{* *}$ \\
\hline $\mathrm{s}_{\mathrm{n}}\left(\mathrm{MKM}^{2}\right)$ & $63,96 \pm 0,08$ & $63,98 \pm 0,08$ & $63,99 \pm 0,12$ & $64,03 \pm 0,08$ & $64,01 \pm 0,08$ & $63,78 \pm 0,10$ \\
\hline $\mathrm{S}_{\mathrm{s}}\left(\mathrm{MKм}^{2}\right)$ & $1282,9 \pm 34,6$ & $1312,3 \pm 52,4$ & $1364,7 \pm 22,7^{*}$ & $1369,2 \pm 26,6^{*}$ & $1359,2 \pm 28,2$ & $1309,8 \pm 28,0^{* *}$ \\
\hline $\mathrm{s}_{\mathrm{n}} / \mathrm{s}_{\mathrm{s}}$ & $0,050 \pm 0,001$ & $0,050 \pm 0,002$ & $0,047 \pm 0,001^{*}$ & $0,047 \pm 0,001^{*}$ & $0,047 \pm 0,001$ & $0,049 \pm 0,001$ \\
\hline
\end{tabular}

Примітки: 1) * - p<0,05 порівняно з групою контролю;

2) ** $-p<0,05$ порівняно з третьою групою.

Поряд із структурними порушеннями м'язових волокон виявлялись і структурні зміни у мікроциркуляторному руслі. Високий ступінь морсологічних змін у судинах спостерігали вже у перші години. В усіх полях зору в перші години характерним був спазм артеріол та нерівномірне розташування ендотелію на базальній мембрані. Патологічні зміни розвивалися в усіх структурних елементах судинної стінки. У судинах мікроциркуляторного русла мали місце нерівномірне розташування епітелію, порушення цілості клітинних мембран та виражений набряк. Клітини ендотелію набухали та ставали округлими, цитоплазма візуалізувалась світлою за рахунок набряку, окремі ядра були гіперхромними. Злущені ендотеліоцити виявлялися в просвітах судин, а у ділянках ендотеліальної вистилки нерідко з'являлися осередки пролірерації.

Інтенсивність таких порушень наростала до кінця першої доби (рис. 2). Кровонаповнення було нерівномірно виражене із переважанням венозного. Розлади гемодинаміки виявлялись дифузними і проявлялися стазом, агрегацією еритроцитів та набряком строми. Характерною особливістю цих змін була наявність круглоклітинних інфрільтратів поблизу судин. Нерідко така інфрільтрація ставала достатньо інтенсивною та поширювалася на пери- та ендомізій. Загальними ознаками патологічної перебудови русла являлись виражені зміни малюнка, рівномірності й щільності мікросудинних сіток. Зміна мікроархітектоніки проявлялась збідненням рисунка судин. Кровонаповнення було нерівномірно виражене із переважанням венозного. Розлади гемодинаміки виявлялись дифузними і проявлялися стазом, агрегацією еритроцитів та набряком строми. Була десрормація артеріол. Мало місце також спадання капілярів, десрормація їх стінок. Ендотелій був гетерогенної форми. Серед незмінених клітин виявлялися округлі, набубнявілі. Частина ендотеліоцитів злущувалася. У ділянках десормованих капілярних сіток спостерігали діапедезні геморагії. Мала місце і деформація посткапілярів та венул, а також їх повнокров'я, паравазальні діапедезні геморагії. Спостерігали і паравазальну клітинну інфрільтрацію та набряк. Перивазальні простори були розширені, строма розрихлена, набрякла. Частково набряк поширюється на перимізій та ендомізій.

Подібні структурні зміни спостерігали і до кінця першого тижня, проте вони були менш інтенсивними та виявлялись локально. Через два тижні були лише локальні потовщення судин мікроциркуляторного русла із проліфрерацією сполучнотканинних елементів та перивазальною клітинною інфрільтрацією.

Висновки При дослідженні скелетної мускулатури задніх кінцівок білих щурів після гострої ішемії, спричи-

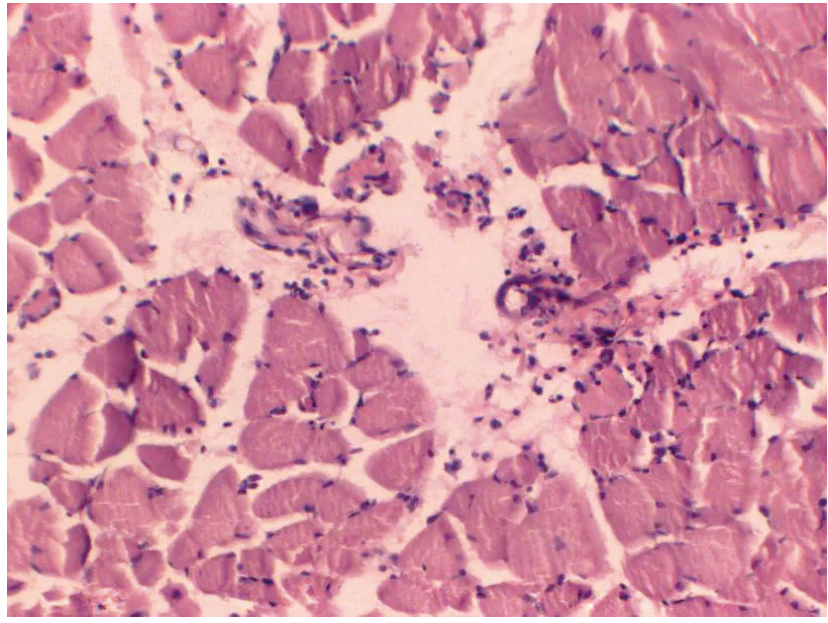

Рис. 2. Поперечний зріз чотириголового м'яза щура. Набряк м'язових волокон, інтерстицію, перивазальний набряк та лейкоцитарна інфрільтрація. Групи ядер у міжклітинному просторі. Перша доба після зняття турнікета. Забарвлення гематоксиліном та еозином. ×100.

неної накладанням турнікета, встановлено, що ремоделювання м'язових волокон проявлялося в основному набуханням, гомогенізацією саркоплазми, порушенням лінійного розміщення ядер в міоцитах та лейкоцитарною інфільтрацією ендо- і перимізію. В окремих випадках спостерігали міоліз із руйнуванням сарколеми та виходом ядер у міжклітинний простір.

Результати гістологічних досліджень препаратів скелетних м'язів щурів виявили і значні структурні зміни в системі мікроциркуляторного русла, що проявлялися спазмом приносної та гіперемією ємнісної ланки мікроциркуляції, внутрішньосудинним стазом, порушенням мікроархітектоніки, значним збідненням судинного малюнка, набряком та порушенням цілості мембран, діапедезними крововиливами, а також наявністю круглоклітинних інфільтратів у периваскулярній зоні. Реактивні порушення розвивались в мікросудинах усіх сегментів та були максимально вираженими до кінця першої доби.

Перспективи подальших досліджень Результати ремоделювання м'язових волокон та судин мікроциркуляторного русла підтверджують розвиток у піддослідних тварин ішемічно-реперфузійного синдрому. Виявлені при цьому закономірності та тенденції можуть бути використані для подальших досліджень та розробки нових напрямків корекції структурно-функціональних порушень м'яких тканин та судин нижніх кінцівок при різних видах компресійної травми. 


\section{СПИСОК ЛІТЕРАТУРИ}

1. Покровский А. В. Национальные рекомендации по ведению пациентов с заболеваниями артерий нижних конечностей / А. В. Покровский, Л. А. Бокерия. - М. : 2013. - 67 с.

2. Губка В. О. Результати лікування хворих із гострою артеріальною ішемією кінцівок / В. О. Губка, І. А. Коноваленко, О. В. Суздаленко // Патологія. - 2015. - № 2 (34). - С. 55-58.

3. Реперфузионный синдром у больных с хронической ишемией нижних конечностей / А. В. Гавриленко, И.И.Дементьева, Д. А. Майтесян. [и др.] // Ангиология и сосуд. хирургия. - 2002. - № 3. - С. 90-95.

4. Гавриленко А.В. Состояние микроциркуляции при реперфузионном синдроме после реконструктивных операций на сосудах нижних конечностей / А. В. Гавриленко, Е. Д. Шабалтас // Хирургия. - 2003. - № 2 - С. 62.

5. Шор Н. А. Наблюдение острой артериальной непроходимости нижней конечности, обусловленной расслоением стенки аорты / Н. А. Шор, И. В. Пронин, В.И.Добрянский // Клінічна хірургія. - 2007. - № 9. - С. 56-58.

6. Сагач В. Ф. Відкривання мітохондріальної пори за умов оксидативного стресу при ішемії-реперфузії тканин стегна / В. Ф. Сагач, Е. Ф. Кахаровський, В. С. Горбовець // Фізіологічний журнал. - 2008. - Т. 54, № 3. - С. 47-51.

7. Фармакологическая профилактика реперфузионного синдрома у пострадавших с тяжелыми сочетанными травмами, сопровождающимися шоком / Ю. С. Полушин, Б. Н. Шах, В. М. Теплов [и др.] // Вестник хирургии имени И. И. Грекова 2013. - T. 172, № 5 - C. 41-45.

8. Safe tourniquet use: a review of the evidence / P. G. Fitzgibbons, C. Digiovanni, S. Hares [et al.] // J. Am. Acad. Orthop. Surg. - 2012 - Vol. 20. - P. 310-319.

9. Drew B. Application of current hemorrhage control techniques for backcountry care: Part One, Tourniquets and Hemorrhage Control Adjuncts / B. Drew, B. Bennett, L. Littlejohn // Wilderness and Environmental Medicine. - 2015. - No. 26. - P. 236-245.

10. Османова А. А. Динамика микроциркуляторного русла при компрессионной травме мягких тканей конечностей и коррекции инфузией перфтторана: дисс. на соискание уч. степени канд. мед. наук : спец. 14.03.01 “Анатомия человека" / А. А. Османова. - Махачкала, 2010. - 162 с.

11. Молекулярные механизмы развития и адресная терапия синдрома ишемии-реперфузии / О. А. Гребенчиков, В. В. Дихванцев, Е. Ю. Плотников [и др.] // Актуальные вопросы анестезиологии и реаниматологии. - 2014. - № 3. - С. 59-67.

12. Blaisdell F. W. The pathophysiology of skeletal musculeishemia and the reperfusion syndrome: a rewiew / F. W. Blaisdell // Cardiovasc. Surg. - 2002. - Vol. 10. - P. 620-630.

13. Меркулов Г. А. Курс патологогистологической техники / Г. А. Меркулов. - л. : “Медицина”, 1969. - 423 с.

Отримано 24.01.18

\section{STRUCTURAL CHANGES IN MUSCLES OF THE HIND LIMBS OF RATS WITH ACUTE ISCHEMIA (EXPERIMENTAL STUDY)}

Summary. Acute limb ischemia occurs as a result of obturation of the lumen of large arteries due to acute thrombosis or embolism, as well as impaired of vascular patency, caused by trauma or compression (including the use of hemostatic tourniquets). In case of elimination of the acute ischemia and restoration of arterial blood supply to the affected limb arises a multifactorial lesion of tissues both ischemic and distant from the site of damage, known as the reperfusion-ischemic syndrome.

The aim of the study - to establish the manifestations of structural changes in muscle fibers and the microcirculatory bed of the skeletal muscles of the hind limbs of rats in case of acute ischemia caused by the application of an arterial tourniquet.

Materials and Methods. The histological and morphometric study the tissues of the four-head muscles of the hind limbs of 60 rats under condition of experimental acute ischemia was performed. There were 11 intact animals in the control group. Acute ischemia was caused by application of SWAT (Stretch-Wrap-And-Tuck) rubber bands on the hind limbs of animals, 5-6 mm width, at the inguinal fold level within 2 hours under thiopental anesthesia. During the experiment, all the animals were divided into 5 study groups of 12 rats in each group. The model of the early postischemic period was represented by groups of animals with reperfusion changes on the 1st, 2nd hour and 1st day after removal of the tourniquet, and model of the late postischemic period on the 7th and 14th days respectively. The histological examination was carried out according to standard methods. The surface layers of the four-headed muscle of the hind limb of rats were studied in the middle third of the thigh below the overlapping area of tourniquet. Morphometric examination was determined by the following parameters: the mean diameter of muscle fibers, the mean cross-sectional area of muscle fibers, the average diameter and the area of nuclei of muscle fibers. Quantitative indicators were processed statistically.

Results and Discussion. All-round analysis of the obtained data revealed that the pathological changes in muscle tissue were aroused in the early period of the postischemic lesions and increased to the end of the 1st day. Histological examination revealed the following changes in the muscle tissue: disorganization of the structural components of the muscle cells, reduction of the striation, friability, fluffiness and rupture of the muscle fibers, violation of their sinuosity, nonlinear arrangement of the nuclei, appearance of the detached necrotic regions and location of the nuclei in the intercellular space. The most significant edema of the muscle tissue occurred on the 1 st day in the third group of rats $((41.73 \pm 0.39) \mu \mathrm{m})$. The average diameter of the muscle fibers in this group was exceeded by $3.37 \%$ the corresponding index $((40.37 \pm 0.54) \mu \mathrm{m})$ of the control group $(P<0.05)$. The average area of the nuclei of the muscle fibers $((64.03 \pm 0.08) \mu \mathrm{m})$ in the third group was only slightly higher than the corresponding value $((63.95 \pm 0.07) \mu \mathrm{m})$ of the control group $(P$ $<0.05)$. The detected decreasing in the nuclear-cytoplasmic ratio in the second $(0.047 \pm 0.001)$ and the third $(0.047 \pm 0.001)$ groups of rats compared with the corresponding indicator of the control group $(0.050 \pm 0.001)(p<0.05)$ may indicate the decreasing in the cellular nuclear activity in the result of ischemic injury.

Conclusions. The results of remodeling of the muscle fibers and the blood vessels of the microcirculatory bed confirm the development of ischemic-reperfusion syndrome in experimental animals. In study of the skeletal muscles of the hind limbs of the white rats after acute ischemia caused by the application of the tourniquet, it was found that the remodeling of the muscle fibers was mainly manifested by edema, homogenization of sarcoplasm, violation of linear arrangement of nuclei in the myocytes and leukocyte infiltration of endoand perimizia, myolysis with the destruction of the sarcolemma and the release of nuclei into the intercellular space. The reactive lesions were developed in the microvessels of all segments and maximally expressed by the end of the 1st day.

Key words: acute ischemia; muscle tissue; muscle fiber; microcirculation; reperfusion-ischemic syndrome. 


\section{СТРУКТУРНЫЕ ИЗМЕНЕНИЯ МЫШЦ ЗАДНИХ КОНЕЧНОСТЕЙ КРЫС ПРИ ОСТРОЙ ИШЕМИИ}

Резюме. Острая ишемия конечности возникает в результате обтурации просвета крупных артерий вследствие острого тромбоза или эмболии, а также нарушения проходимости сосудов, вызванного их травмами или сжатием (включая применение кровеостанавливающих турникетов). В случае ликвидации острой ишемии и восстановлении артериального кровеснабжения пораженной конечности возникает мультифакторное поражение ишемизированных и отдаленных от места повреждения тканей, носящее название реперфузионно-ишемического синдрома.

Цель исследования - установить проявления структурных изменений мышечных волокон и микроциркуляторного русла скелетных мышц задних конечностей крыс при острой ишемии, вызванной наложением артериального турникета. Материалы и методы. Было проведено гистологическое и морфометрическое исследование тканей четырехглавых мышц задних конечностей 60 крыс в условиях экспериментальной острой ишемии. В контрольной группе было 11 интактных животных. Острую ишемию вызывали путем наложения резиновых жгутов SWAT (Stretch-Wrap-And-Tuck) на задние конечности животных шириной 5-6 мм на уровне паховой складки в течение 2 ч под тиопенталовым обезболиванием. Во время эксперимента животные были разделены на 5 исследуемых групп по 12 крыс в каждой группе. Модель раннего постишемического периода была представлена группами животных с реперфузионными изменениями на 1; 2 ч и 1 день после снятия турникета, а модель позднего постишемического периода - на 7 и 14 сутки после снятия турникета. Гистологическое исследование проводилось по общепринятым методикам. Исследовались поверхностные слои четырехглавой мышцы задней конечности крыс в средней трети бедра ниже участка наложения жгута. При морфометрическом исследовании определялись следующие показатели: средний диаметр мышечных волокон, средняя площадь поперечного сечения мышечных волокон, средние диаметр и площадь ядер мышечных волокон. Количественные показатели обрабатывались статистически.

Результаты исследований и их обсуждение. Результаты анализа полученных данных установили, что патологические изменения мышечной ткани возникали уже в ранний период постишемического поражения и нарастали к концу 1 суток. При гистологическом исследовании наблюдались следующие изменения тканей мышц: дезорганизация структурных компонентов мышечных клеток, уменьшение исчерченности, разрыхленность, розволокненность и разрывы мышечных волокон, нарушение их извилистости, нелинейное расположение ядер, появление отдельных некротических очагов и расположение ядер в межклеточном пространстве. Наиболее значительный отек мышечной ткани имел место в первые сутки в третьей группе крыс $((41,73 \pm 0,39)$ мкм). Средний диаметр мышечных волокон в этой группе превышал на 3,37 \% соответствующий показатель $((40,37 \pm 0,54)$ мкм) контрольной группы $(p<0,05)$. Средняя площадь ядер мышечных волокон $(64,03 \pm 0,08)$ мкм) в третьей

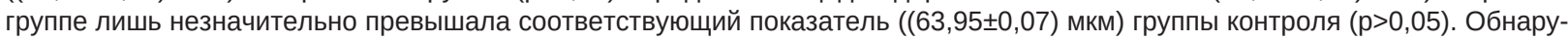
жено уменьшение показателя ядерно-цитоплазматического соотношения во второй $(0,047 \pm 0,001)$ и третий $(0,047 \pm 0,001)$ группах крыс по сравнению с соответствующим показателем группы контроля $(0,050 \pm 0,001)(p<0,05)$, что может свидетельствовать об уменьшении ядерной активности клеток в результате их ишемического повреждения.

Выводы. Результаты ремоделирования мышечных волокон и сосудов микроциркуляторного русла подтверждают развитие у подопытных животных ишемическо-репердузионного синдрома. При исследовании скелетной мускулатуры задних конечностей белых крыс после острой ишемии, вызванной наложением турникета, установлено, что ремоделирование мышечных волокон проявлялось в основном отеком, гомогенизацией саркоплазмы, нарушением линейного расположения ядер в миоцитах и лейкоцитарной инсильтрацией эндо- и перимизия, миолиз с разрушением сарколеммы и выходом ядер в межклеточное пространство. Реактивные нарушения развивались в микрососудах всех сегментов и были максимально выраженными к концу первых суток.

Ключевые слова: острая ишемия; мышечная ткань; мышечное волокно; микроциркуляторное русло; реперфузионно-ишемический синдром. 